\title{
The Experience of Multilocal Living: Mobile Immobilities or Immobile Mobilities?
}

\author{
Cédric Duchêne-Lacroix, Monika Götzö, Katrin Sontag
}

\section{Aude, Bernd and Florence: three cases of multilocal living}

Aude is sitting on the sofa in her little apartment in Switzerland. Bookshelves and photos line the walls, a big sofa, a small table and her desk with her computer leave little space. Aude says that this apartment is the first place for her, which she calls "mon chez moi" in her life. Aude is in her mid-thirties and works as nurse. She grew up in a small town in France.

Aude worked in five places in different countries before coming to Switzerland. In each place she lived, she made a good friend to whom she still has close contact and visits regularly. Two of her friends made her godmother to their children and a third godchild is on its way. "Godmothering" became her way of "doing family". One of her friends has four children she raises alone with little income. For Aude, this is "her family". She commutes to their place regularly during her long weekends and supports them with financial and practical help - "thanks to Easyjet", as she emphasised.

Altogether, Aude has four main places where she stays and sleeps. Firstly, she works night shifts and has a room with a bed at the hospital. Secondly, she has an apartment where her job is and where the interview took place. Thirdly, she has her family in France. Finally, she visits her friends in Canada regularly. This multilocal setting resembles the image of an "archipelago of different islets" (Duchêne-Lacroix 2011, 2014b) where her life takes place.

In Aude's narration, it is remarkable how the activities of her life are finely separated and split up between these places. The hospital is her working place. The apartment is her living place, where she is alone and can withdraw. Her friend in France is her family, where she helps with the children and in the household.

1 | We understand "doing family" as a set of reflexive or routinised social practices which create, activate or change the family as a Gemeinschaft (Schier 2010; Von Arx and Duchêne-Lacroix 2014). 
Canada is the place for recovery, where she feels free from all duties and spends time in nature.

Bernd meets me at his company in a sparsely furnished meeting-room with white walls, equipped with elegant black chairs and a white table. The only striking element is a little chessboard, which again features black and white. Bernd is about 50 years old and the Chief Executive Officer (CEO) of an Information Technology (IT) company with around 100 employees, situated in Switzerland. He has three children, who live in Scandinavia with his wife. The family did not want to move when Bernd decided to go to Switzerland. It would have been difficult for his wife to find a job that suited her in Switzerland for language reasons and both of them did not want to have a situation where Bernd worked and his wife had to be a housewife, which they assumed was still more common in the Swiss system than in Scandinavia. The couple, thus, decided that the working and education system in Scandinavia suited them better and that they would keep two households. Moving to Switzerland for Bernd was his fifth move. He previously worked in and set up different companies.

Bernd spends around one third of his time at each of his living places plus one third on business trips worldwide. Bernd's life seems structured and framed by his work:

So for me, the most satisfying thing is that there are companies in this world and products in this world that exist which probably wouldn't exist if I hadn't been involved in building them, and so to create this new entity is to me the most interesting thing. That's fundamentally what drives me.

His living islets do not seem as specified as Aude's, but rather fluid in their content and meaning. When he travels or spends time at his family home, he still works. At the same time, his family also comes to visit him or they are in touch via Skype in a virtual space. His social contacts take place through his work. His arrangement seems fluid; the movement, rather than the mooring at a certain place, seems an essential part of his life.

The interview with Florence takes place at an international conference, in a separate small group room we were able to organise for our meeting. Florence is a professor at a Canadian university and is in her late fifties. Florence moved with her parents from Europe to the USA and, since then, has been moving back and forth between the USA, Canada and Europe, where she has a second apartment. She speaks several languages fluently. Members of her family of origin also live in different countries, language zones and continents. Florence has lived in different countries and worked in different job positions before. She interprets diverging roles, interests and social co-operation forms as parts of her own identity and, therefore, as important to her. That is why, she explained, she tries to link and combine these aspects wherever possible. As an academic, she sees many possibilities to do this. Her life and work are interwoven and express a high degree 
of conscious steering. Florence chooses places, people and projects according to her own perspectives of meaningful academic work, which is best characterised as co-operative thinking and exchange. The geographic places and the institutions are secondary. She describes some of her academic partners as close friends whom she meets regularly all over the world, creating new networks with friends of her friends for new projects. The stays differ between a short-time exchange of ideas for applications and academic semesters or years outside her "home" university. Since her husband died a few years ago, she takes longer trips. Her movements, thus, take different forms, but the meaning and goals of her mobility show a certain stability.

The three cases are taken from our ongoing research projects. ${ }^{2}$ All three of them live multilocally, i. e. they live in more than one place at the same time. They have further characteristics in common. Similar legal preconditions facilitate their international mobility. Their main residences are the places where they work, on the one hand, and the places where their family and social relations take place, on the other hand. Their form of multilocality is transnational and highly mobile. All of them have experienced migration and mobility within their biographies before. Aude and Bernd come from middle-class families and did not experience much mobility themselves as children. However, while Bernd's parents were settled in one place, Aude's father worked as a long-distance bus driver. Florence, born to parents of Eastern European background with experiences as refugees in the Second World War, moved at the age of nine with her parents from Western Europe to the USA, where she lived till the end of secondary school. In spite of these common features, the cases also put forward three different constellations of dealing with multiple living spaces which challenge classic dichotomies of moving and staying. We will explore this point in our contribution.

Multilocal living poses an interesting angle on mobility and immobility as it combines both and provides a third perspective epistemologically as well as empirically. Through the analysis of these three cases, we will ask how they live habitually in and between their living places and what role mobility and immobility play for them. Beforehand, we will briefly introduce multilocal living studies.

2 | All interviews are taken from the body of material of our ongoing research projects. Katrin Sontag and Monika Götzö are working in the Swiss National Science Foundation project "Living and Working in Different Places: Biography and Work Migration of the Highly Qualified - a Perspective from Cultural Anthropology". The project focuses on highly qualified migrating entrepreneurs (Katrin Sontag) and academics (Monika Götzö). Both researchers work with qualitative, biographical interviews. Cedric Duchêne-Lacroix is working in the Swiss National Science Foundation project "Multilocal Living Arrangements in Switzerland. Mobility in the Interplay of Material, Social and Biographical Conditions". This project focuses on adults with a main residence in Switzerland who live in more than one habitual residence within or outside Switzerland. The research team, also constituted by Margrit Hugentobler, Nicola Hilti and Helmut Schad, conducted a mixed method-based empirical research method including a survey and semi-structured interviews. The cases are anonymised. 


\section{MULTILOCAL LIVING AND THE STUDY OF MOBILITY}

Classic studies on migration and mobility were mostly based on a dichotomy of moving and staying (Götzö and Sontag 2015), and mobility and immobility were interpreted as separate and separable entities. Moreover, the focus often lay on the mobile, while immobility seemed somewhat eclipsed. This understanding of immobility goes back to the "double container perspective" (Duchêne-Lacroix, Hilti, and Schad 2013) of the national, geographical container as a basic entity, on the one hand, the so-called "methodological nationalism" (Wimmer and Glick Schiller 2002), and individual confinements to households and fixed residences within a bureaucratic statehood system, on the other hand. Sedentariness accounted for the "normal" state of affairs, while migrating and mobile lives were constructed as "the other", and migrants were seen as those who compromised this kind of social order (Raphaël 1986; Wimmer and Glick Schiller 2002).

This categorisation of being either "here" or "there", mobile or immobile, becomes more complex for people who live multilocally. Multilocal living, "the practice of living in several habitual places at least once a year" (Duchêne-Lacroix 2014a) poses a third perspective epistemologically as well as empirically. It subsumes mobility and immobility, dwelling and moving and asks for the individual semantics, boundaries and intersections of these two concepts (Hilti 2009).

The emerging studies on multilocal living trace their origin back to research on inter alia migration/integration, mobility and social arrangements, the ethnography of second homes and residential economy. Already used - in a small circle - in the late-1970s by geographers in Africa (Watts and Prothero 1981), the parent term "multilocality" describes specific circular migration forms and, in other contexts, geographically fragmented life (Hilti 2013; Rolshoven 2004). Individual and social links covering the distance are a common issue in studies on transnationality and multilocality. Multilocal residents do not live just here or there, but here and there following a certain pattern of movement. Some researchers in geography, history, anthropology, sociology and development studies, rediscovering the importance of the local, use the term "translocalism" to describe and analyse forms of transnational relations (Appadurai 1996; Brickell and Datta 2010; Freitag and Oppen 2009; Greiner and Sakdapolrak 2013; Steinbrink 2009; Verne 2012). Multilocality has been used with similar heuristic goals (Kingsolver 1996; Miranda 1996). With this last development, the national border is no more a criterion of the definition of the phenomenon, but a significant parameter of analyses. Multilocal living contributes to this shift, with - in addition - a focus on the intermittent (co)presence of (a group of) people at each living place and on place making. 
Multilocal living is a frequent spatial practice, ${ }^{3}$ which takes different forms under different contexts: living apart together couples (Duncan and Phillips 2010; Schlemmer 1995), "shuttles" (job-related commuting) and a part of the "overnighters" (Reuschke 2010; Schneider, Limmer, and Ruckdeschel 2002), children of post-separation families with joint custody (Schier 2010), transmigrants (Glick-Schiller, Basch, and Blanc-Szanton 1995) or (trans)national secondary residents (Bonnin and Villanova 1999; Quinn 2004; Stedman 2006). The phenomenon of multilocal living concerns directly or indirectly a large part of society and affects all areas of life and can, thus, be considered a total social fact (Mauss 1923).

Zygmunt Bauman or Yi-Fu Tuan characterised modern life as fluid and increasingly mobile and, therefore, less locally fixed (Bauman 2000; Tuan 1977). Forms of multilocal living could be interpreted this way (as always on the road between here and there or as a life transition). Multilocal living can diversify the geographic and social mobility of the dwellers, but also reduce the intensity of specific mobility, such as daily long-distance commuting between a working place and home. Furthermore, local social life can be the same at each living place. Moreover, multilocal living also presents a multi-sedentariness at different usual living places. "A place is (...) an instantaneous configuration of positions. It implies an indication of stability" (Certeau 1984, 117). Someone could, for instance, commute daily and yet live a home-loving lifestyle at one specific place to which he or she returns frequently. Multilocal living can be lived as a sort of inertia or long-term balance between important living aspects or places of the dwellers. The materiality of multilocal living or, more generally, the "things" (Latour 2005) linked with it can reinforce the inertia (Weichhart and Kazig 2009).

\section{MULtilocal LiVING AS AN EXPRESSION OF LIFE STRATEGIES}

The situation of multilocality is not a period of transition, but rather a regular living condition for all three protagonists. However, in each case, their situation is structured by very different long-term life strategies and visions.

Aude, the nurse, tells her story in a way that gives emphasis to the places and their meaning to her and leaves her in the role of having to organise her life around them. She imagines that life has guided her to where she now finds herself. Aude's islets appear to have biographically accumulated and now have to be taken care of. Aude talks about the importance of "having roots" and says that she does not want her children to be "uprooted" and forced to move. Cosiness and belonging are also important features within her narration. Aude dreams of social advancement. She

3 | About a quarter of the Swiss population lives multilocally (in more than one usual dwelling place during a year) and another quarter lived multilocally (Schad et al. 2014), more than 11 per cent in France with another empirical design (Imbert et al. 2014). 
talks of a bigger house, of being the owner instead of the tenant, being in control, making decisions.

Bernd, the IT entrepreneur, on the other hand, sets up his islets to optimise his professional situation. His passion, goals and rewards seem to lie in bringing his ideas and products into reality. The steps he has taken so far seem pragmatic and well-planned. He seems happy and content with his situation and says he would move on if one day it no longer fulfilled him.

Currently I would say both Switzerland and Scandinavia are home, but I don't view it as a permanent home, this is it forever [...] I wouldn't say it's desirable, but the alternative is also not desirable, so neutral [...] I mean, if the alternative was I'm based in one place and this is my home, the restriction that implies, I don't like that restriction.

Bernd connects places that are beneficial for him to form a space within which he is constantly on the move. Mobility and fluidity are his way of creating opportunities and meaning. Living in this translocal space also means that he does not feel any particularly strong attachment to any one place or country, but sees himself rather as European.

Florence worked strategically on becoming an academic the way she considered it best for herself: to link theory and "something on the ground", i. e. projects in community building or social welfare, and sharing ideas with interesting people across the globe. Therefore, she looks for and creates opportunities and the contexts for these to emerge in order to realise what matters to her as a good academic life, and what makes sense temporarily as well as in the long run.

Florence describes herself as an academic and intellectual kind of "old school intellectual-traveller". She realises her scientific work in a transnational manner. Her narrations are shaped by a strong value-based attitude towards science, which she describes as collaborative, with high impact to social questions around the world.

In all three cases, multilocal living is a fundamental means to realise their basic life strategies and live a meaningful life by linking and stabilising islets of importance.

\section{IM-/MOBILITY IN THREE DIMENSIONS OF SPACE}

However, in which ways and dimensions do mobility and immobility play a role in the three cases' practices of daily life?

For Aude, the year is well-planned. She plans her long weekends with her family, her trips to Canada and her shifts at the hospital well ahead. This planning also serves the economic purpose of finding affordable flight tickets. Aude travels light with little luggage and keeps personal belongings in the house of her family. 
For her, the four locations between which she moves are fixed points of reference to which she connects strongly and emotionally. When she talks about each of the places, a different emotional space and atmosphere opens up during the interview.

She is strongly attached to her few chosen friends and mentions that it is not easy to create new bonds at her current places. She repeatedly mentions her longing and how much she misses her godchildren. Her attachment to these relationships is a strong bond. She talks, for example, about her emotional stress when her working schedule was changed and she was not able to follow her travel schedule.

On the level of geographical movement, of travel, Aude is a highly mobile person. She travels transnationally at least once a month. Yet, there is ambivalence between her mobility and immobility. Her points of mooring are so important for Aude that the places, the people and the times of travel seem like fixed pillars within her life. Moreover, the space which spans between her and her four main living islets is defined through well-known geographical and emotional paths, which do not seem to change much and are in this way static and, thus, provide a space that is geographically as well as socially immobile. They are fixed points within her "inner topography"4. Mobility and immobility work in two ways and on different levels for Aude: firstly, her mobility makes her inflexible and, thus, immobile. Her living islets force her to be mobile, but this mobility takes place within very rigid immobile structures. She has to make plans, stick to a fixed time schedule and follow certain paths of travelling in order to get to her fixed places and social relations. Equally, one could say: because of this immobility, she has to be mobile. Aude has to commute, travel and spend different parts of her life with different people, thus, being mobile in social and geographical space, precisely because this basic arrangement is immobile.

This ambivalence is also part of the relationships between the actors. Her boss, her friends, her children and potential new friends all have different understandings of mobility and flexibility, distance and closeness. For her boss, it is difficult to understand how someone without children can be inflexible. Planning her weekends ahead makes her mobile, but inflexible at the same time.

The same ambivalence can be seen in her professional life. Aude appears geographically and socially mobile, often changing places and also employers and, thus, social surroundings. However, within social space, Aude is also immobile as she does not want to change her position or change to a new job. She does not want to progress hierarchically and prefers to stabilise herself on the same professional level. She needs to attend further training courses in order to be electable even for a new job on her level; this is difficult for her to finance and her employer is not willing to finance it. There is, thus, a certain immobility as far as her career is concerned.

4 | We would like to thank Jacques Picard for introducing this concept. 
The interview with Bernd, the CEO, was arranged by his assistant who changed the scheduled time twice. Bernd's time planning seemed quite tight. He travels two to three times per week by plane.

Before he decided to go to Switzerland, Bernd had mapped out advantages and disadvantages of different industrial centres and then chose Switzerland, because it promised the best conditions for his business and research interests. If another place had appeared more promising, he would probably have had no issues switching.

We looked where to put the company, [...] so we chose Switzerland because it was hiring talent. The ability to access talent internationally, and the cost and the ability to raise money were the things that made us choose Switzerland [...] We had a big spreadsheet with all the different places.

His anchorage seems rather functional and situative. His business, research ideas and the results he wants to create and realise are most important to him. Where he anchors seems secondary and dependent on the conditions he finds. He does not call any of his places "home" - in fact, his daily workloads do not seem to change much. His daily life is structured as if there was one meta-level: work. Moving and travelling seem part of his normal daily life and also part of his financial outlook on life. There is no debate on planning and optimising costs with a sparse budget, as in Aude's case.

Bernd's social relations involve mostly his work or working interests, and are spread out across different places. The only fixed point to which he regularly travels seems to be the locations of his family, who did not move to Switzerland with him.

In Bernd's strategy, both living places - the place of the company and the place of the family, provide a geographically and socially immobile structure, which provides him with a context he needs. However, the connecting piece, his work and the way he understands it, could also be interpreted as an immobile, determining and, in a way, consistent factor in his life strategy which "forces" him to be mobile, because he needs to find a suitable context each time he sets up an enterprise. It also forces him to travel in order to stay in touch with business partners and clients.

Florence, the professor in Canada, plans the steps in her life in a thoughtful, conscious way. Her considerations focus on linking values, interests, people and places, and projects for their realisation. Academic life and work are, thereby, what she calls the "centre of her life". To her, "home"

is work, it's more of a space for reflection and feelings and thinking, and [...] relations and relationships to be more congruent [...] with my own values and the kind of place I would be teaching in. And, also the kind of students who would be there.

Florence's moves are shaped by her imaginations of good academic collaborative work and intellectual life. Science is more than work to her, it is a statement for 
freedom in thinking and collaboration. This has been true for her since the beginning of her academic path as she moved from Europe back to the USA to become a university student in a place where she hoped to find conditions for collaborative thinking and the development of ideas and projects. Today, Florence follows people and ideas rather than places, and tries to realise her claims there. As an example, she chose a state university for her Ph.D. because she expected more open-minded students and professors, and refused to study in a highly ranked private university in the same town, where she had also been accepted. Today, her floating mobility is structured by settled friendships and academic networks, all of them stable, though growing. As she is a well-known and highly appreciated academic herself, she often receives visitors (at times when she is not travelling by herself) at the university where she works in Canada. Florence maintains permanent connections to colleagues around the world through the internet.

With regard to mobility and immobility, Florence mentions both social and geographic immobilities and mobilities. Geographically, she lives a multilocal life, spending weeks or semesters abroad, attending conferences all over the world. She leaves her home for work and leisure time at least once a year to live in Paris, where she bought an apartment many years ago. She likes spending time abroad for longer periods, to settle in another environment to get familiar with other contexts she is interested in. In social terms, she is an academic, but strongly interested in community building activities and political contributions to social issues. She has changed her roles several times during her work life, but increasingly emphasises the importance of "bridging" different aspects of interests and personality. Florence evaluates locations with regard to their ability to offer contexts for "bridging". The values concerned are stable though. The locations should provide access to interesting people, projects and a certain way of collaboration. Neither the geographic place nor the reputation of the university seems of prime interest to her. The importance of the combination of people, interests, ideas and shared values to contribute to social questions as such, seems to be mirroring a certain degree of stability. At the same time, Florence is highly mobile in geographic terms in order to reach her goals and needs. Academia provides, therefore, a special space she knows how to use in a skilled way. However, today's change of academic life conditions due to financial logics seems to challenge her interests and perceptions of what academic work should be. At the end of the interview, she says that she is not sure if she could follow her path the way she has done since she started to link her different interests. Academia seems to be changing from an enabling site to a limiting condition, a situation which contradicts her ideals and realities of an intellectual life.

All three cases reveal that mobility and immobility are closely related and interact in many ways, as much as they are ambivalent concepts. From the perspective of multilocal living, mobility and immobility are not separable, not even analytically. 
Immobility in the context of multilocal living often involves an obligation to move in order to bridge fixed places separated by time and space. Hence, the necessity to move expresses the capacity to be mobile and, simultaneously, creates a situation of multi-fixation. Therefore, repetitive forms of mobility can be perceived as immobility. The attachments may also work in an enabling or limiting way.

In all three cases, mobility can be a precondition for different forms of stability. In addition, immobility operates in the shape of stability regarding space, social relations and interests. Referring to John Urry (2000), who put forward a realm of analysis which includes mobilities of people, objects, ideas and virtual travel, and Johanna Rolshoven, who understands mobilities along similar lines as "studying movements of people, their bodies, thoughts, actions and things" (2011, 54; our translation), we derive a framework of three dimensions of geographic, social and subjective space from our material that are interlinked in their expression of mobility and immobility. Regarding social immobility or social mobility, we do not mean the classic understanding of "upwards or downwards" movements within social systems, but, more broadly, the interaction with different groups of people. In the subjective dimension of space, we can observe changes or stability in the representations, strategy, interests or capabilities of a multilocal dweller beyond changes in the geographic and social dimensions.

Aude's permanent moving takes place between a fixed set of places, paths and people for a set of reasons. Even though she moves a lot, there is a certain inflexibility geographically, socially and also on the level of ideas. Her mobility is, thus, structured by a multilocal fixedness or mobile immobility.

Bernd is very clear about his professional goals and visions and creates a translocal space within which he moves irregularly and with seeming ease, combining different places and people in order to produce his products and expand his company. This goal, thus, poses the stability and link between his movements.

Florence is highly mobile in social and geographic terms and this mobility creates a certain stability with regard to her goal to find places where she can combine her academic, political and private interests. Her permanent moving creates, thus, a stable space to follow her interests and to realise her idea of herself and her life visions. As long as she can be mobile, there is no need to reconsider her visions for a good academic life, and, in this again, lies a certain inertia and stability.

For all three of them, mobility, change and flexibility in some dimensions of space are a precondition for stability and immobility. Mobility and immobility can, thus, be enabling, limiting or even threatening, depending on the life strategy they are part of and on the context and perspective of the observer. Therefore, our argument points to the interrelations between places, islets, ideas or lifestyles within a multilocal life that can be seen as stable or even fixed, and mobility that bridges these places or opportunities. Nevertheless, our case studies reveal how variable experiences are of what is mobile, immobile, enabling or even limiting. Whereas mobility for Bernd and Florence is a precondition for a meaningful life, and 
multilocality is a consequence of their mobile life, Aude's biography constructed a multilocal life and has to deal with mobility and its costs in terms of job opportunities and financial aspects. To name the variability in a more analytical way, we will introduce the concept of spatiality regimes, as it is within this context that mobility and immobility or stability are experienced and evaluated by our three protagonists.

\section{Spatiality Regimes}

We define the concept of a "spatiality regime" as the set of conditions, rules and habits activated in a geographic, social and biographically situated framework which allows, influences or forces the mobility and anchoring practices of specific people for a specific period of time. Such rules derive from the political, bureaucratic or economic situation from institutions, etiquette, habitus and norms. A spatiality regime is not a geographic space or place itself, but the spatiality of this place, generated by its practices and its social preconfiguration. Spatiality regimes are constantly co-created by people in certain places, times and interactions (cf. Certeau 1984, 117). We could say that spatiality regimes constitute areas for actions which (dis)enable people to act in a certain way, within certain conflicts, in a complex but predetermined way, so that "special" effects of spatiality regimes can be observed and distinguished. In other words, the spatiality regime structures agency and makes the situation intelligible for the activation of capabilities (Näre 2014). Spatiality regimes can be written and unwritten rules, visible and invisible, and it is, among others, through clashes in the understanding of mobility and immobility that spatiality regimes become visible. The concept of spatiality regimes allows us to take into account the specific configuration of space and, thus, analyse the perspective from which mobility or immobility are defined as such.

Multilocal living, as a geographical phenomenon, simultaneously configures and is influenced by spatiality regimes, capabilities and individual "life strategies" and "tactics" (Certeau 1984, 117).

A dominant aspect of the spatiality regimes within which the three actors' multilocal lives are embedded is the professional context. The current configuration in the place where Aude works includes a competitive job market, which demands further education. Aude's professional life, from the point of view of geographical mobility, seems very mobile, but, seen from within the spatiality regime of her "job islet", she feels she is not mobile enough, because she does not want to pursue further education or further career steps. Demands from the outside job market and the educational policies form a spatiality regime and Aude experiences how her environment demands a greater mobility from her regarding further education than she is able or willing to provide and, thus, she appears immobile. 
Regarding Aude's understanding of "family", the spatiality regime of her workplace follows different norms from her own. Her boss thinks of a family as a biological two-parent nuclear family, while Aude calls her godchildren "her family". Commuting regularly to see her family, in the view of her colleagues, was only legitimate if the family is recognised as a "real family". Her way of "doing family" does not fit the norm of this particular spatiality regime and she experiences this as a conflict within her working life. Aude's framework for decision-making is, thus, spatially restrained.

Bernd's company also depends on a certain configuration of spatiality regimes and his way of making use of it. He analyses existing legal situations in different countries of the world, investment behaviour and recruitment possibilities and then chooses a place for his activities based on the existing information. Bernd, one could conclude, takes advantage of spatiality regimes by picking the combination that suits him best. However, he is subject to the expectations and duties of the spatiality regime he moves in and, at the same time, his own vision of running his enterprise. In doing so, he interlinks conditions of the spatiality regime to his life strategy.

The academic world poses the dominant spatiality regimes in which Florence moves. She experienced its demands, support and limits when, for example, she met her French husband and French universities were interested neither in American sociology nor in an American degree. Her husband's academic degree, at the same time, was not valued in the USA. Finally, they found the solution in bilingual Canada, where both experienced a general openness to what they had done before. Florence learned to rely on and work with academic networks and, thus, expand her possibilities within the academic spatiality regime. Her networks work like bridging systems: everybody is part of different spatiality regimes and, thus, possesses different local knowledge. Through these networks and connections, people pass on their knowledge.

As we have seen, spatiality regimes operate in multilocal lives as a force that both enables and limits im/mobilites. They influence individual interactions and decision-making processes.

The meaning of mobility and immobility becomes visible when actors set their life strategies in relation to certain spatiality regimes. Aude, for example, only realises which norm of "doing family" her boss follows, which family is considered a "real family" in this spatiality regime, when she is not allowed the same freedom of travelling to see her family as her colleagues. Other spatiality regimes, such as the laws Bernd followed when setting up his company, are clearly mapped out so that he could study and compare them beforehand. Florence, with her experience, makes use of a lifetime of informal learning about different spatiality regimes and is interacting with them with seeming ease. When considering actual changes in academia, she mentions rules, regulations and opportunities changing in terms 
of limited freedom for academics to travel and network in favour of a localised, competitive university with strategic partners.

Aude's approach to multilocal living is functionalist and segmented. Each of her islets has a different function and meaning and she herself has a different social position in each local network. Bernd's and Florence's islets seem to lack that specification, but are held together by personal visions and ideas as well as a specific social position, which remains the same. Both of them move within translocal spatiality regimes: Florence in the academic world and Bernd in his business networks. And yet, all three of them transgress, connect, experience and co-create different spaces.

Mobility and immobility are relational in so far as they appear between certain protagonists at a given place at a certain time. Relations between intersecting im/ mobilities can be made visible through ethnography; spatiality regimes are one analytical frame of looking at these relationships. We argue that the meaning of mobility and immobility is structured and judged by spatiality regimes, as they determine the "norm".

Spatiality regimes may hinder, support, allow and change movements. However, the interaction with spatiality regimes is not one-sided, but also depends on the actor and his or her living strategies. Interacting with spatiality regimes, thus, resembles continuous "work" of learning about and balancing mobility and immobility. The question of mobility and immobility finally becomes a question of self-positioning within different spatiality regimes.

\section{CONCLUSION}

The three cases presented reveal how mobility and immobility are flexible, interrelated concepts. Our protagonists experience and evaluate both mobility and immobility in different ways as, for example, enabling or limiting dimensions. This also becomes true regarding the meaning of places: Aude evaluates places in terms of functions, whereas Bernd and Florence aim for opportunities. Both opportunities and functions are handled by our protagonists with knowledge and capabilities, and it is the basic life strategy that gives orientation towards mobility and immobility. Nevertheless, the multilocal life which our cases follow demands high capacities to cope with spatiality regimes that shape mobility and immobility. To what extent the protagonists can make use of places and in which way they experience mobility and immobility is highly dependent on what we called spatiality regimes. As a set of certain rules, expectations, possibilities and constraints, spatiality regimes shape experiences and demands to cope with distance, absence (Duchêne-Lacroix 2009), different local rules or expectations of groups or people 
to manage their everyday life. Whether something is considered mobile or immobile, acceptable or not, possible or not, depends on this configuration.

To conclude, we suggest looking at mobility and immobility as related terms, culturally loaded with expectations of the "normal" or the "divergent". These culturally coded conceptions are challenged - as our three cases reveal - in everyday life in the context of a multilocal life as well as in different spatiality regimes, such as health care, business and science. Ethnographic studies can contribute to a better understanding of actual life forms under the increasing urge to mobilise.

\section{RefERENCES}

Appadurai, A. 1996. Modernity at Large: Cultural Dimensions of Globalization. Minneapolis: University of Minnesota Press.

Bauman, Z. 2000. Flüchtige Moderne. Frankfurt am Main: Suhrkamp.

Bonnin, P., and R. de Villanova, eds. 1999. D'une maison l'autre: Parcours et mobilités résidentielles. Grane: Creaphis editions.

Brickell, K., and A. Datta, eds. 2010. Translocal Geographies: Spaces, Places, Connections. Farnham: Ashgate.

Certeau, M. de. 1984. The Practice of Everyday Life. Berkeley: University of California Press.

Duchêne-Lacroix, C. 2009. "Mit Abwesenheit umgehen: Kontinuität und Verankerung einer transnationalen Lebensführung jenseits territorialer Abgrenzungen." Edited by Gabriele Sturm and Christine Weiske. Informationen zur Raumentwicklung, 1/2: 87-98.

Duchêne-Lacroix, C. 2011. “Archipel." In Praxen der Unrast: Von der Reiselust zur modernen Mobilität, edited by Jens Badura, Cédric Duchêne-Lacroix, and Felix Heidenreich, 135-146. Berlin: Lit-Verlag.

Duchêne-Lacroix, C. 2014a. "Habiter plusieurs logements habituels: éléments conceptuels et typologiques d'une pratique plurielle." In Questionner les mobilités résidentielles à l'aune de la multilocalité, edited by Philippe Hamman, Maurice Blanc, Cédric Duchêne-Lacroix, Tim Freytag, and Caroline Kramer, 33-60. Strasbourg: Neothèque.

Duchêne-Lacroix, C. 2014b. "Archipel oder die Territorialität in der Multilokalität der Lebenswelt.” In Mobil und doppelt sesshaft: Studien zur residenziellen Multilokalität, edited by Peter Weichhart and Peter Rumpolt, 218-239. Abhandlungen zur Geographie und Regionalforschung 17. Wien: Institut für Geographie und Regionalforschung.

Duchêne-Lacroix, C., N. Hilti, and H. Schad. 2013. "L'habiter multilocal: discussion d'un concept émergent et aperçu de sa traduction empirique en Suisse." Revue Quételet 1: 63-89. 
Duncan, S., and M. Phillips. 2010. "People Who Live Apart Together (LATs) - How Different Are They?” Sociological Review 58 (1): 112-134.

Freitag, U., and A. V. Oppen. 2009. Translocality: The Study of Globalising Processes from a Southern Perspective. Leiden: Brill.

Glick-Schiller, N., L. Basch, and C. Blanc-Szanton. 1995. "From Immigrant to Transmigrant: Theorizing Transnational Migration.” Anthropological Quarterly 68 (1): 48-63.

Götzö, M., and K. Sontag. 2015. “Ansätze für eine kulturanthropologische Untersuchung hochqualifizierter Migrantinnen und Migranten: Eine Bestandsaufnahme.” In Schweizerisches Jahrbuch für Wirtschafts- und Sozialgeschichte (29), edited by Brigitte Studer, Caroline Arni, Walter Leimgruber, Jon Mathieu, and Laurent Tissot, 303-313. Zürich: Chronos.

Greiner, C., and P. Sakdapolrak. 2013. "Translocality: Concepts, Applications and Emerging Research Perspectives.” Geography Compass 7 (5): 373-384.

Hilti, N. 2009. "Multilokales Wohnen: Bewegungen Und Verortungen.” Informationen zur Raumentwicklung, no. 1/2: 77-86.

Hilti, N. 2013. Lebenswelten multilokal Wohnender: Eine Betrachtung des Spannungsfeldes von Bewegung und Verankerung, Stadt, Raum und Gesellschaft. Stuttgart: Springer VS.

Imbert, C., G. Deschamps, É. Lelièvre, and C. Bonvalet. 2014. "Vivre dans deux logements: surtout avant et après la vie active." Population et Sociétés, 507: 4.

Kingsolver, A. E. 1996. Plurinationality and Multilocality: Some Explanations of Identity and Community Before and After NAFTA in Mexico and the U.S. CLRC. University of California at Santa Cruz, Chicano/Latino Research Center.

Latour, B. 2005. Reassembling the Social: An Introduction to Actor-Network-Theory. Oxford: Oxford University Press.

Mauss, M. 1923. Essai sur le don: forme et raison de l'échange dans les sociétés archaïques. L'Année Sociologique, Classiques des sciences sociales 2: 30-186.

Miranda, A. 1996. "L’agencement de la multilocalité depuis le lieu d'origine. Le cas de Casalvieri (sud de l'Italie) et ses migrants.” Espaces Sociétés 80: 271-296.

Näre, L. 2014. “Agency as Capabilities: Ukrainian Women's Narratives of Social Change and Mobility." Women's Studies International Forum 47: 223-231.

Quinn, B. 2004. "Dwelling through Multiple Places: A Case Study of Second Home Ownership in Ireland." In Tourism Mobility and Second Homes: Between Elite Landscapes and Common Ground, edited by C. Michael Hall and Dieter K. Müller, 45-59, Clevedon: Channel View Publications.

Raphaël, F. 1986. “'L'étranger' de Georg Simmel.” In Georg Simmel: la sociologie et l'expérience du monde moderne, Collection "sociétés", edited by Patrick Watier, 257-280. Paris: Méridiens/Klincksieck.

Reuschke, D. 2010. "Die Multilokale Lebensform Des Shuttelns." In Multilokales Wohnen, 73-209. 
Rolshoven, J. 2004. "Mobilität und Multilokalität als moderne Alltagspraxen." In Zweitwohnsitze und kulturelle Mobilität, edited by Johanna Rolshoven and Ueli Gyr, 205-212. Projektberichte, Zürich: Institut für Populäre Kulturen.

Rolshoven, J. 2011. "Mobilitätskulturen im Parkour. Überlegungen zu einer kulturwissenschaftlichen Mobilitätsforschung." In Mobilitäten. Europa in Bewegung als Herausforderung kulturanalytischer Forschung, edited by Reinhard Johler, Max Matter, and Sabine Zinn-Thomas, 52-60. Münster: Waxmann.

Schad, Helmut, N. Hilti, M. Hugentobler, and C. Duchêne-Lacroix. 2014. "Multilokales Wohnen in der Schweiz - erste Einschätzungen zum Aufkommen und zu den Ausprägungen.” In Mobil und doppelt sesshaft Studien zur residenziellen Multilokalität, 176-201. Abhandlungen zur Geographie und Regionalforschung 17. Wien: Institut für Geographie und Regionalforschung.

Schier, M. 2010. "Multilokaler Alltag erwerbstätiger Eltern: Erweiterte Optionen oder erhöhte Probleme für die Lebensführung?” In Unsichere Zeiten: Verhandlungen des 34. Kongresses der Deutschen Gesellschaft für Soziologie in Jena 2008, edited by Hans-Georg Soeffner, CD Rom. Wiesbaden: VS Verlag für Sozialwissenschaften.

Schlemmer, Elisabeth. 1995. "Living apart together', eine partnerschaftliche Lebensform von Singles?” In Das Individuum und seine Familie: Lebensformen, Familienbeziehungen und Lebensereignisse im Erwachsenenalter, edited by Hans Bertram, 363-398. Opladen: Leske + Budrich.

Schneider, N. F., R. Limmer, and K. Ruckdeschel. 2002. Berufsmobilität und Lebensform: Sind berufliche Mobilitätserfordernisse in Zeiten der Globalisierung noch mit Familie vereinbar? Schriftenreihe des Bundesministeriums für Familie, Senioren, Frauen und Jugend. Stuttgart: Kohlhammer.

Stedman, R. C. 2006. "Understanding Place Attachment among Second Home Owners." American Behavioral Scientist 50 (2): 187-205.

Steinbrink, M. 2009. Leben zwischen Land und Stadt: Migration, Translokalität und Verwundbarkeit in Südafrika. Wiesbaden: VS Verlag für Sozialwissenschaften.

Tuan, Y.-F. 1977. Space and Place: The Perspective of Experience. Minneapolis: University of Minnesota Press.

Urry, J. 2000. Sociology beyond Societies: Mobilities for the Twenty-first Century. New York: Routledge.

Verne, J. 2012. Living Translocality: Space, Culture and Economy in Contemporary Swahili Trade. Stuttgart: Franz Steiner Verlag.

Von Arx, M., and C. Duchêne-Lacroix. 2014. "Reproducing, Budgeting, Coexisting, Caring, Networking, "Culturing”, Positioning, Identifying, Displaying, ... Familienherstellungsleistung im multilokalen transnationalen Kontext." In Questionner les mobilités résidentielles à l'aune de la multilocalité, edited by Philippe Hamman, Maurice Blanc, Cédric Duchêne-Lacroix, Tim Freytag, and Caroline Kramer, 289-322. Strasbourg: Neothèque, Strasbourg. 
Watts, S. J. and T. M. Prothero. 1981. Population Mobility and Multilocality in Ilorin, Kwara State, Nigeria. Liverpool: University of Liverpool, Department of Geography.

Weichhart, P., and T. Kazig. 2009. "Die Neuthematisierung der materiellen Welt in der Humangeographie.” Berichte zur deutschen Landeskunde. 83: 109-128.

Wimmer, A., and N. Glick Schiller. 2002. "Methodological Nationalism and the Study of Migration.” European Journal of Sociology 43: 217-240. 
Bereitgestellt von | Universitaetsbibliothek Basel

Angemeldet

Heruntergeladen am | 17.09.18 17:22 